\title{
Study on Chromium-Binding Capacity of Callitriche cophocarpa in an Aquatic Environment
}

\author{
Joanna Augustynowicz • Joanna Kyzioł-Komosińska • \\ Sylwester Smoleń $\cdot$ Andrzej Waloszek
}

Received: 14 July 2012/Accepted: 26 November 2012/Published online: 18 December 2012

(C) The Author(s) 2012. This article is published with open access at Springerlink.com

\begin{abstract}
The aim of the present study was to investigate the binding strength of chromium $(\mathrm{Cr})$ ions to aquatic macrophyte Callitriche cophocarpa. Shoots of the plants were incubated in a natural water solution containing $\mathrm{Cr}(\mathrm{III})$ or $\mathrm{Cr}(\mathrm{VI})$ at a concentration ranging from 0.5 to $4 \mathrm{mM}$ under laboratory conditions. We found that C. cophocarpa has an extremely high capacity to bind $\mathrm{Cr}$. The average level of accumulation reached 28,385 or $7,315 \mathrm{mg} \mathrm{kg}^{-1}$ dry weight for plants incubated with $\mathrm{Cr}(\mathrm{III})$ or $\mathrm{Cr}(\mathrm{VI})$, respectively. Shoots incubated in a $0.5 \mathrm{mM}$ concentration of $\mathrm{Cr}$ (III) for 5 days removed almost $100 \%$ of the metal from solution. The major pool of the bound $\mathrm{Cr}$ (III) ions follows the strongest mechanism of metalbinding to an organic matter. In contrast, we found that only $25 \%$ of $\mathrm{Cr}(\mathrm{VI})$ ions are bound into the metallo-organic
\end{abstract}

\section{J. Augustynowicz $(\square)$}

Department of Botany and Plant Physiology, Faculty of Horticulture, University of Agriculture in Kraków, Al. 29 Listopada 54, 31-425 Kraków, Poland

e-mail: augustyn@ogr.ur.krakow.pl

J. Kyzioł-Komosińska

Institute of Environmental Engineering, Polish Academy of Sciences, ul. M. Skłodowskiej-Curie 34, 41-819 Zabrze,

Poland

e-mail: joasia@ipis.zabrze.pl

\section{S. Smoleń}

Department of Soil Cultivation and Fertilization in Horticulture, Faculty of Horticulture, University of Agriculture in Kraków, Al. 29 Listopada 54, 31-425 Kraków, Poland e-mail: ssmolen@ogr.ur.krakow.pl

\footnotetext{
A. Waloszek

Department of Plant Physiology and Biochemistry, Faculty of Biochemistry, Biophysics and Biotechnology, Jagiellonian University, ul. Gronostajowa 7, 30-387 Kraków, Poland

e-mail: andrzej.waloszek@uj.edu.pl
}

compounds and $57 \%$ of $\mathrm{Cr}(\mathrm{VI})$ exists in an easily remobilizable form. Activity of a photosynthetic electron transport (as $F_{\mathrm{V}} / F_{\mathrm{M}}$ ) was evaluated with respect to the Cr-binding mechanism. Our results contribute to the development of knowledge on processes controlling bioremediation of heavy-metallic compounds in aquatic systems.

Chromium $(\mathrm{Cr})$ is the sixth most abundant transition metal on Earth. When it is naturally incorporated into minerals, it exhibits a low chemical mobility and transport during erosion. However, the natural background of $\mathrm{Cr}$ is dwarfed by anthropogenic contamination. Global discharge of $\mathrm{Cr}$ is higher than those of lead $(\mathrm{Pb})$, mercury $(\mathrm{Hg})$, and cadmium (Cd) (Kabata-Pendias and Mukherjee 2007). $\mathrm{Cr}$ and $\mathrm{Cr}$ compounds are used in a wide variety of industrial and manufacturing applications, including steel alloy fabrication, plated product fabrication, nonferrous alloy metal fabrication, textile industry (for dyeing and printing), leather industry (for tanning), and manufacture of green varnishes, inks, paints, and glazes as well as in ceramics. In water and wastewater, $\mathrm{Cr}$ exists primarily in two oxidation forms: $\mathrm{Cr}(\mathrm{VI})$ and $\mathrm{Cr}(\mathrm{III}) . \mathrm{Cr}(\mathrm{III})$ dominates as soluble $\mathrm{Cr}^{3+}$ at $\mathrm{pH}<3$. As $\mathrm{pH}$ increases, $\mathrm{Cr}(\mathrm{III})$ hydrolyzes to $\mathrm{CrOH}^{2+}$, $\mathrm{Cr}(\mathrm{OH})_{2}^{+}, \mathrm{Cr}(\mathrm{OH})_{3}$, and $\mathrm{Cr}(\mathrm{OH})_{4}^{-}$. In slightly acidic to alkaline conditions ( $\mathrm{pH} \mathrm{6-12)} \mathrm{Cr}(\mathrm{III})$ can precipitate as an amorphous $\mathrm{Cr}(\mathrm{OH})_{3}$. Depending on $\mathrm{pH}(6-8)$ and the concentration, aqueous solutions of $\mathrm{Cr}(\mathrm{VI})$ mainly contain dichromate $\left(\mathrm{Cr}_{2} \mathrm{O}_{7}{ }^{2-}\right)$ or chromate $\left(\mathrm{CrO}_{4}{ }^{2-}\right)$ anions. The $\mathrm{Cr}(\mathrm{VI})$ ions exert very toxic effects on living organisms. The high toxicity is due to a high redox potential of $\mathrm{Cr}(\mathrm{VI})$, its mobility, and its ability to penetrate biological membranes. In contrast, $\mathrm{Cr}(\mathrm{III})$ is an essential microelement in the 
mammalian metabolism. The role of $\mathrm{Cr}(\mathrm{III})$ in plant physiology has not yet been elucidated (Zayed and Terry 2003; Kabata-Pendias and Mukherjee 2007). Both, Cr(III) and $\mathrm{Cr}(\mathrm{VI})$ species exist in aquatic systems. The concentration of $\mathrm{Cr}$ (III) in water is lower than the concentration of $\mathrm{Cr}(\mathrm{VI})$ because $\mathrm{Cr}$ (III) has an ability to form complexes with organic ligands. The equilibrium between these two forms of $\mathrm{Cr}$ depends on many factors. These factors include $\mathrm{pH}$, concentration of reducers (Fe(II), organic compounds), oxidizing mediators $\left(\mathrm{O}_{2}\right.$, manganese oxides) and complexing agents (organic matter) (Kotaś and Stasicka 2000).

Common physicochemical treatment technologies that remove $\mathrm{Cr}$ pollution are based on reduction-oxidation, precipitation, accumulation, and sorption (Hawley et al. 2004). Phytoremediation belongs to a group of biological treatment technologies. It is based on the use of plants to eliminate a contaminant from the surrounding environment. Plants pose mechanisms of contaminant remediation related to the all of the mentioned strategies; however, the details of these mechanisms are not clear. A great deal of research has been conducted on phytoextraction, which is defined as an ability of a plant to remove and sequester a pollutant in its body (Prasad 2004).

An excellent review describing different types of adsorbents used in removal of $\mathrm{Cr}(\mathrm{III})$ and $\mathrm{Cr}(\mathrm{VI})$ from water is provided by Mohan and Pittman (2006). The materials - such as activated carbons, ion-exchange resins, and polysaccharide-based materials-are commercially used as sorbents. Disadvantages of using the above-mentioned materials include high operational costs and problems with the regeneration process. Therefore, the new low-cost adsorbents that demonstrate a high sorption capacity are clearly needed. Alive or dried microorganisms, fungi, algae, and higher plants are promising biosorbents of $\mathrm{Cr}$. Studies of organic and inorganic materials for their applicability as sorbents in the removal of heavy metal ions from water and wastewater must not only consider the sorption capacity of the investigated materials but also the mechanisms by which metals are bound. The forms and types of the bindings are crucial for the mobility of a metal as well as its remobilization and bioavailability. A proper treatment of waste sorbents, i.e., recovery of the metal or its disposal, depend on the type of metal binding. Sequential extraction (SE) (Tessier et al. 1979) can identify main binding sites and quantify the strength of a metal binding to particulates. Different methods of chemical SE are used to fractionate metals in various environmentally reactive or hydromorphic phases of soil (Jaradat et al. 2006; Jain et al. 2008; Romaguera et al. 2008), sediment (Alomary and Belhadj 2007) and solid wastes (Ayari et al. 2008; Soco and Kalembkiewicz 2009). These chemical SE methods can differentiate between the following fractions: metals retained in a pore solution and adsorbed onto surface of particles, exchangeable species, metals bound to carbonates or manganese $(\mathrm{Mn})$ and iron $(\mathrm{Fe})$ oxides, metals bound to an organic matter and sulphides, and a residual phase of metals bound in lithogenic minerals. SE may also be applied to homogenous materials, e.g., organic matter, such as peat and plants, e.g., mosses (Mouvet and Claveri 1999; KyziołKomosińska et al. 2006).

Callitriche cophocarpa (water starwort), the widely abundant aquatic macrophyte, was recently shown to remediate $\mathrm{Cr}(\mathrm{VI})$ in water (Augustynowicz et al. 2010). Compared with other aquatic and terrestrial accumulators that use root systems to accumulate (rhizofiltrate) metal ions, $C$. cophocarpa is capable to uptake $\mathrm{Cr}$ by shoot tissues. We previously showed that after incubation with $50 \mu \mathrm{M}\left(2.6 \mathrm{mg} \mathrm{L}^{-1}\right) \mathrm{Cr}(\mathrm{VI})$, C. cophocarpa can accumulate $>1,000 \mathrm{mg} \mathrm{Cr} \mathrm{kg}^{-1}$ dry weight (dw) while maintaining its physiological status (Augustynowicz et al. 2010).

The aim of the present study was to determine whether C. cophocarpa can be used as an efficient biosorbent of dissolved, highly concentrated up to $4 \mathrm{mM}\left(210 \mathrm{mg} \mathrm{L}^{-1}\right)$ $\mathrm{Cr}(\mathrm{III})$ and $\mathrm{Cr}(\mathrm{VI})$ ions in a contaminated aquatic environment. In our experiments, concentrations of metals were chosen according to the $\mathrm{Cr}(\mathrm{III})$ and $\mathrm{Cr}(\mathrm{VI})$ content in electroplating wastewater and used in the adsorption tests (Tessier et al. 1979; Kyzioł-Komosińska and Kukułka 2008). We used a live plant material to mimic conditions that occur in a natural environment. During experiments, the physiological status of shoots was measured by evaluation of the photosynthetic light phase activity (as photosystem [PSII] activity by $F_{\mathrm{V}} / F_{\mathrm{M}}$ [see Maxwell and Johnson 2000; Strasser et al. 2004]) in relation to $\mathrm{Cr}$ remediation by the plant tissue. To measure the strength of Cr binding to $C$. cophocarpa, we used the SE method developed earlier by Tessier et al. (1979) and modified by Kersten and Förstner (1990). This technique is based on fractionation of $\mathrm{Cr}(\mathrm{III})$ and $\mathrm{Cr}(\mathrm{VI})$ ions in respect to their susceptibility to remobilization.

\section{Materials and Methods}

\section{Plant Material}

Callitriche cophocarpa Sendt. was collected in the Dłubnia River in southern Poland $50^{\circ} 16^{\prime} \mathrm{N} / 19^{\circ} 56^{\prime} \mathrm{E}$ from February to November 2010. The material was thoroughly washed with tap water. Only healthy, mature shoots, approximately $10 \mathrm{~cm}$ in length, were separated and used for further experiments.

Incubation of Plants in Cr Solutions

The $\mathrm{Cr}$ solutions were prepared using filtrated (pore size $0.4 \mu \mathrm{m}$; Millipore) river water derived from the natural 
nonpolluted $C$. cophocarpa environment. Water analysis was performed after inductively coupled plasma (ICP)mass spectrometry spectroscopy (ELAN 6100; Perkin Elmer) (PN-EN ISO 9963-1:2001) as well as titration methods (PN-ISO 9297:1994; PN-EN ISO 17294-1:2007). The spectrometer was calibrated using the ICP multielement standard (Merck). The average amount $\left(\mathrm{mg} \mathrm{L}^{-1}\right)$ of elements were as follows: $10.07 \mathrm{Na}^{+}, 4.61 \mathrm{~K}^{+}, 111.70$ $\mathrm{Ca}^{2+}, 13.71 \mathrm{Mg}^{2+}, 5 \times 10^{-3} \mathrm{Fe}^{2+}, 7 \times 10^{-3} \mathrm{Mn}^{2+}$, $1.8 \times 10^{-2} \mathrm{Zn}^{2+}, 2 \times 10^{-3} \mathrm{Cu}^{2+}, 10^{-3} \mathrm{Mo}^{6+}, 32.40 \mathrm{Cl}^{-}$, $32.90 \mathrm{SO}_{4}{ }^{2-}, 344.00 \mathrm{HCO}_{3}{ }^{2-}, 8.20 \mathrm{NO}_{3}{ }^{2-}, 0.06 \mathrm{PO}_{4}{ }^{3-}$, and $0.20 \mathrm{BO}_{3}{ }^{3-}$. The level of heavy metals $\mathrm{Pb}, \mathrm{Hg}, \mathrm{Cd}$, and $\mathrm{Cr}$ did not exceed $1 \mu \mathrm{g} \mathrm{L}^{-1}$. The electrical conductivity of water was equal to $0.63 \mathrm{mS} \mathrm{cm} \mathrm{cm}^{-1}, \mathrm{pH}=7.80$, and $E_{\mathrm{h}}$ $($ redox potential $)=256 \mathrm{mV}$. Cr was added as $\mathrm{K}_{2} \mathrm{Cr}_{2} \mathrm{O}_{7}$ in the case of $\mathrm{Cr}(\mathrm{VI})$ or $\mathrm{Cr}_{2}\left(\mathrm{SO}_{4}\right)_{3} \cdot 18 \mathrm{H}_{2} \mathrm{O}$ in the case of $\mathrm{Cr}$ (III) (POCH, Poland). The $\mathrm{Cr}$ salts were dissolved to obtain the final concentrations of $0.5 \mathrm{mM}\left(26 \mathrm{mg} \mathrm{L}^{-1}\right)$, $1 \mathrm{mM}\left(52 \mathrm{mg} \mathrm{L}^{-1}\right), 1.5 \mathrm{mM}\left(78 \mathrm{mg} \mathrm{L}^{-1}\right), 2 \mathrm{mM}(104 \mathrm{mg}$ $\left.\mathrm{L}^{-1}\right)$, and $4 \mathrm{mM}\left(208 \mathrm{mg} \mathrm{L}^{-1}\right) \mathrm{Cr}$. $\mathrm{pH}$ of the solutions decreased after addition of $\mathrm{Cr}$ salts. The starting $\mathrm{pH}$ of $\mathrm{Cr}(\mathrm{VI})$ was correlated with the $\mathrm{Cr}$ concentration and varied from 7.12 to 6.30. To prevent the precipitation of minerals, the $\mathrm{pH}$ of the water was decreased to 5.5 before application of $\mathrm{Cr}$ (III). Consequently, the $\mathrm{pH}$ values of the $\mathrm{Cr}$ (III) solutions were in the range of 4.90-4.54. The amount of $\mathrm{Cr}$ added (mM) was not significant in relation to the molar concentration of the intracellular solution, which usually is equal to a few hundred milimoles/liter. The shoots $(3.5 \mathrm{~g})$ were incubated in $150 \mathrm{ml} \mathrm{Cr}$ solution. The tests were performed for 5 days accordingly to previously published data (Kyzioł-Komosińska and Kukułka 2008). Incubations were conducted under controlled light and temperature conditions: $16 \mathrm{~h}, 35 \mu \mathrm{mol}$ photons $\mathrm{m}^{-2} \mathrm{~s}^{-1}$ (LF 36W/54, Piła, Poland), $8 \mathrm{~h}$ darkness, at $25^{\circ} \mathrm{C}$. The light intensity was comparable with that of the natural Callitriche environment. During the experiments, the cultures were slightly rotary-shaken to imitate river flow and to improve element exchange. As a control, plants were incubated in identical conditions but without addition of $\mathrm{Cr}$.

\section{Determination of Cr Content}

After incubation, the plant material was thoroughly washed three times with distilled water and then dried for $24 \mathrm{~h}$ at $105{ }^{\circ} \mathrm{C}$. The samples were then mineralized in a heated nitric acid (POCH, Torun, Poland) and finally diluted to $10 \mathrm{ml}$. ICP-optical emission spectroscopy (Prodigy Teledyne Leeman Labs) was used to measure the total $\mathrm{Cr}$ content in the mineralized plant material as well as the $\mathrm{Cr}$ solutions. The spectrometer was calibrated using the ICP single-element standard (Merck). Analysis was performed at $205.552 \mathrm{~nm}$.
SE

The $\mathrm{Cr}$ ions were fractionated with respect to the major mechanisms of their sorption to $C$. cophocarpa but mainly with respect to the binding strength and susceptibility to remobilization. A classical seven-step SE scheme developed by Tessier et al. (1979) and modified by Kersten and Förstner (1990) was used. The fractionating procedure consisted of a subsequent treatment of the Cr-containing organic matter with extractants of increasing strength. This procedure enables to distinguish the metal enrichment "pools" F0 through F6 of increasing binding strength and decreasing mobility as follows:

- $\mathrm{F} 0=$ the pool of $\mathrm{Cr}$ ions occurring in the free-water space of the cell wall (the water-soluble fraction).

- $\quad \mathrm{F} 1$ and F2 = the pools of Cr ions bound by electrostatic hydrogen and Van der Waals' attraction between $\mathrm{Cr}$ ions and the surface charged cell wall or/and by exchange ion process between $\mathrm{Cr}$ ions and cations $\left(\mathrm{K}^{+}\right.$, $\mathrm{Ca}^{2+}, \mathrm{Mg}^{2+}, \mathrm{Fe}^{2+}$ ) located in functional groups occurring on the surface of plant biosorbent walls (e.g., carboxyl, phenol hydroxyl) instead of $\mathrm{H}^{+}$ions (mobile fractions).

- $\mathrm{F} 3$ and F4 = the pools of $\mathrm{Cr}$ ions trapped by chelation/ complexation process of the surface functional groups (e.g., carboxyl, hydroxyl phenol, amine) into $\mathrm{Cr}$-organic acid complexes (mobilizable fractions).

- $\quad \mathrm{F} 5=$ the pool of very strong stable binding of $\mathrm{Cr}$ ions; $\mathrm{Cr}$ ions may be transported across the cell membrane and are located within the cell (according to accumulation process).

- Residual pool F6 = metals that are stably incorporated into the lithogenic crystallites of the mineral fraction. F6 does not occur in pure organic matter.

Plant samples were incubated in a solution containing $4 \mathrm{mM}$ Cr. The samples $(0.5 \mathrm{~g})$ were then dried, homogenized, and analyzed by SE. Each of the abovedescribed six fractions were centrifuged $(20 \mathrm{~min}$ at $10,100 \times g)$ to separate the solid phase. In all extracts, $\mathrm{Cr}$ content was determined using a Thermo Jarrell Ash model AA-Scan-1 atomic absorption spectrophotometer equipped with $\mathrm{Cr}$ hollow cathode lamp under optimized measurement conditions. The spectrometer was calibrated using a standard $\mathrm{Cr}$ solution (Merck). The signal was measured with background correction (deuterium lamp) at the optical flame (A-Ac) height. The $\mathrm{Cr}$ content in soluble fraction (F0) from samples incubated in media consisting of $\mathrm{Cr}(\mathrm{VI})$ was determined using the UV-Vis method $(\lambda=546 \mathrm{~nm}$; Varian Cary 50 Scan spectrophotometer) with 1,5-diphenylocarbazide in the acid medium. 
Measurement of Chlorophyll Fluorescence

Kinetics of the induction of chlorophyll fluorescence was recorded using Handy-PEA (Hansatech, UK) employing a chlorophyll fluorometer using the standard procedure. Fluorescence was induced by the red light: $\lambda_{\max }=$ $650 \mathrm{~nm}, 1,500 \mu \mathrm{mol}$ photons $\mathrm{m}^{-2} \mathrm{~s}^{-1}$. Samples of leaves were preadapted in darkness for $30 \mathrm{~min}$ on wet filter paper rings. Recorded curves were then analyzed using the software PEA-Plus (provided by Hansatech, UK), and photosynthetic functional parameter $F_{\mathrm{V}} / F_{\mathrm{M}}$-the maximum potential quantum yield of PSII was calculated.

\section{Statistics}

Up to five independent experiments were performed for each measurement. The results were analyzed using either a one-way or two-way analysis of variance (ANOVA) $(P \leq 0.05)$, and means were compared using Tukey's test.

\section{Results}

Cr Binding: Accumulation Study

The accumulation of $\mathrm{Cr}$ ions by shoots was proportional to the applied concentration of the metal (Fig. 1a). However, the accumulation levels detected for 1.5 and $2 \mathrm{mM}$ data points were not significantly different. Significant differences in $\mathrm{Cr}$ accumulation by shoots were found when $4 \mathrm{mM}$ concentrations of $\mathrm{Cr}$ were present in solution. The amount of accumulated metal strongly depended on its speciation. The average accumulation level of $\mathrm{Cr}$ during the 5-day exposure was 4.8 times greater in the case of plants incubated in $\mathrm{Cr}(\mathrm{III})$ solution than in those incubated in $\mathrm{Cr}(\mathrm{VI})$. The highest metal content $\left(28,385 \mathrm{mg} \mathrm{kg}^{-1} \mathrm{dw}\right)$ was found in plants exposed to $4 \mathrm{mM} \mathrm{Cr}(\mathrm{III})$. Under the same condition, plants incubated in $\mathrm{Cr}(\mathrm{VI})$ solution accumulated up to $7,315 \mathrm{mg} \mathrm{kg}^{-1} \mathrm{dw}$. The level of $\mathrm{Cr}$ in control plants did not exceed $5 \mathrm{mg} \mathrm{kg}^{-1} \mathrm{dw}$. The accumulation of $\mathrm{Cr}$ by plants was correlated with the decrease of $\mathrm{Cr}$ content in the incubation medium (Fig. 1b). The statistical analysis showed differences in the correlation between $\mathrm{Cr}$ removal and the initial concentration of metal in solution for $\mathrm{Cr}(\mathrm{III})$ and $\mathrm{Cr}(\mathrm{VI})$. This correlation was linear in the case of $\mathrm{Cr}(\mathrm{III})$. In contrast, the removal of $\mathrm{Cr}(\mathrm{VI})$ was constant at all tested concentrations (compare homogenous groups). The most pronounced removal of $\mathrm{Cr}$ was measured in the case of $\mathrm{Cr}(\mathrm{III}) ; \leq 98.8 \%$ of the $\mathrm{Cr}$ ions were removed from the solution after a 5-day treatment of the shoots. Efficiency of the $\mathrm{Cr}(\mathrm{VI})$ removal from the solution was, on average, 5.1 times lower. The concentration factor defined as $\mathrm{Cr}$ concentration in shoots
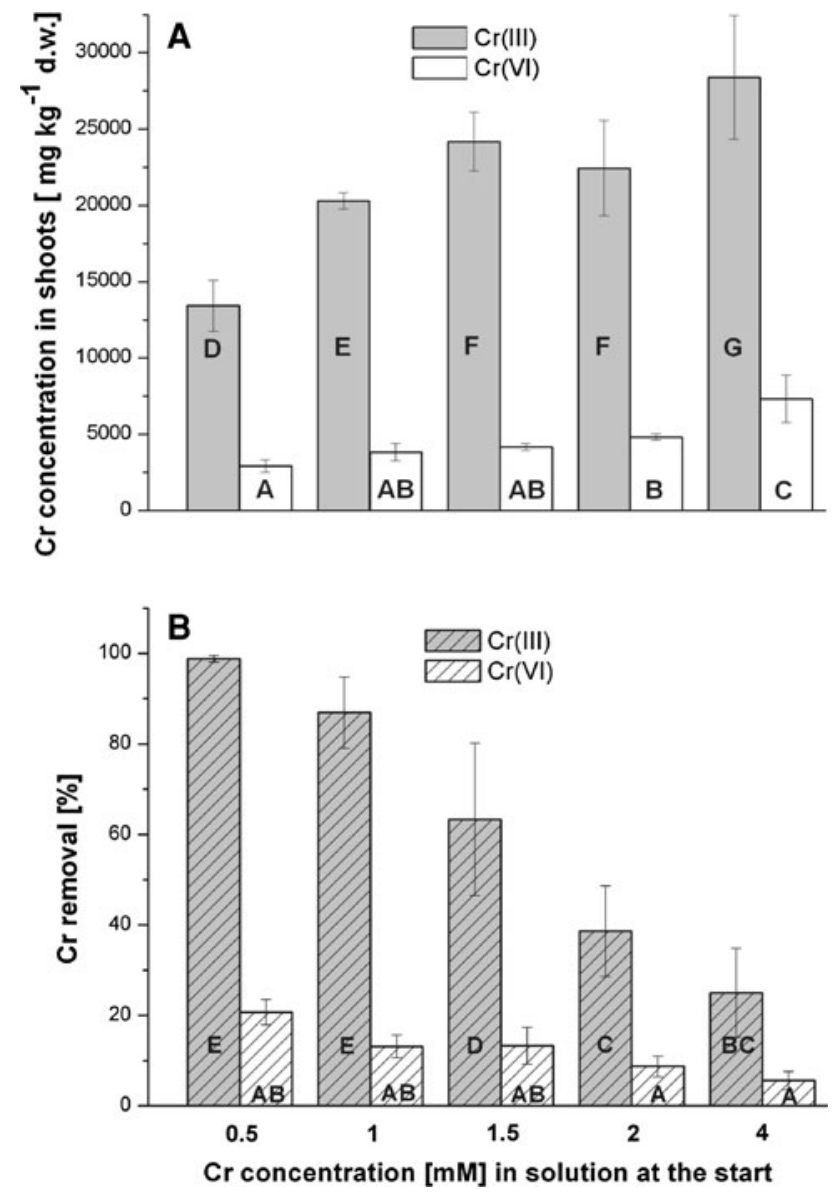

Fig. 1 Accumulation ( $\mathrm{mg} \mathrm{kg}^{-1} \mathrm{dw}$ ) (a) and removal (\%) (b) of $\mathrm{Cr}$ ions by shoots of $C$. cophocarpa during a 5-day incubation in relation to different $\mathrm{Cr}$ concentrations $(\mathrm{mM})$ in medium. Different letters denote statistically significant differences (ANOVA and Tukey's test; $P \leq 0.05)$. Error bars represent SDs. Each value is an average of six independent measurements

Table 1 Bioconcentration factor of $\mathrm{Cr}$ defined as a ratio of the metal concentration in shoots $\left(\mathrm{mg} \mathrm{kg}^{-1} \mathrm{dw}\right)$ to the concentration of the element dissolved in the solution $\left(\mathrm{mg} \mathrm{kg}^{-1}\right)$

\begin{tabular}{llc}
\hline Initial Cr concentration $(\mathrm{mM})$ & \multicolumn{2}{l}{ Concentration factor } \\
\cline { 2 - 3 } & $\mathrm{Cr}(\mathrm{III})$ & $\mathrm{Cr}(\mathrm{VI})$ \\
\hline 0.5 & 517 & 112 \\
1 & 390 & 74 \\
1.5 & 310 & 53 \\
2 & 216 & 46 \\
4 & 136 & 35 \\
\hline
\end{tabular}

( $\mathrm{mg} \mathrm{g}^{-1} \mathrm{dw}$ ) versus $\mathrm{Cr}$ concentration in solution $\left(\mathrm{mg} \mathrm{g}^{-1}\right.$ ) ranged from 517 to 35 depending on the metal valence and its initial concentration (Table 1).

The $\mathrm{pH}$ of the solutions increased during the experiment in the all tested conditions, except from the media including the highest $\mathrm{Cr}$ (III) content, which are known to 
be strong acids. The increase of $\mathrm{pH}$ in the case of the $\mathrm{Cr}(\mathrm{VI})$ solution was similar irrespective of its initial concentration and gained 0.83 . The $\mathrm{pH}$ of $\mathrm{Cr}$ (III) media increased in the range from 0.13 to 1.41 . The decrease of $\mathrm{pH}(0.42$ of $\mathrm{pH}$ units) was found in the highest $\mathrm{Cr}(\mathrm{III})$ concentration. No color changes were observed, and there was no precipitation in the $\mathrm{Cr}$ (III) solutions. No color change was detected in the $\mathrm{Cr}(\mathrm{VI})$ solution either. However, some precipitation in the $1-4 \mathrm{mM} \mathrm{Cr}(\mathrm{VI})$ concentrations were observed.

\section{Cr Binding: SE}

SE analysis showed a significant diversity in the main binding mechanism of $\mathrm{Cr}$ adsorbed to the studied plant material (organic matter). Examination of $\mathrm{Cr}$ binding strength after incubation of plants in $\mathrm{Cr}$ (III) solution showed that $\mathrm{Cr}$ was present in strong stable fractions (F5 and F4). In the mobile fractions (F0 and F1), Cr occurrence was small, i.e., 2.54 and $6.73 \%$, respectively (Fig. 2). The

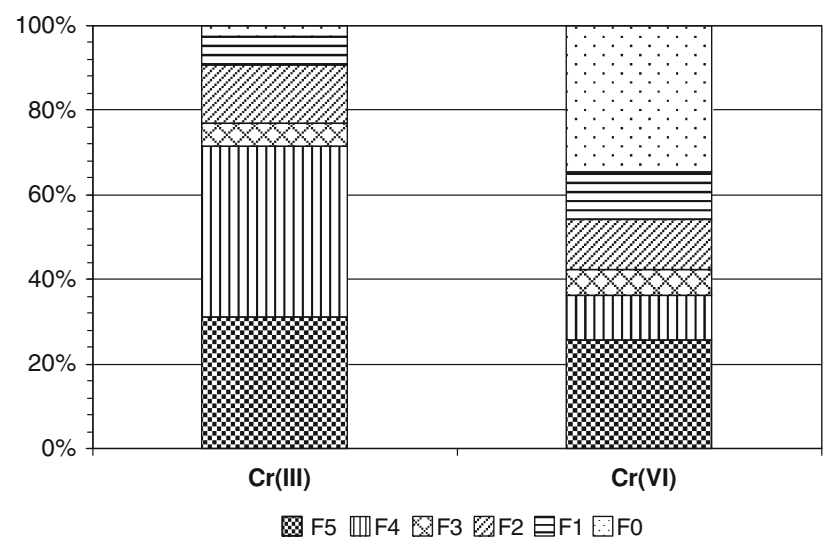

Fig. 2 Sorption pools of different binding strength for $\mathrm{Cr}(\mathrm{III})$ and $\mathrm{Cr}(\mathrm{VI})$ binding onto $C$. cophocarpa after incubation of plants in $4 \mathrm{mM} \mathrm{Cr}$ concentration. $\mathrm{FO}$ pool of $\mathrm{Cr}$ ions occurring in the freewater space of the cell wall (the water-soluble fraction), $F 1$ and $F 2$ pools of $\mathrm{Cr}$ ions bound by the electrostatic, hydrogen, and Van der Waals' attraction (mobile fractions), F3 and F4 pools of $\mathrm{Cr}$ ions trapped by chelation/complexation process (mobilizable fractions), F5 pool of very strong, stable binding of $\mathrm{Cr}$ ions. Three independent measurements were performed for each sample presence of $\mathrm{Cr}$ in $\mathrm{F} 0$ and $\mathrm{F} 1$ is important because these fractions show $\mathrm{Cr}$ that can be remobilized in various environmental conditions. Particularly, the highest relative amount of the metal adsorbed was in F4 (40.52 \%) and F5 $(30.99 \%)$. The remaining fractions, F3 and F2, contained 5.45 and $13.77 \%$, respectively, of the total absorbed load (Table 2).

Fractionation of the adsorbed $\mathrm{Cr}$ after incubation of the material in $\mathrm{Cr}(\mathrm{VI})$ media showed different distribution of $\mathrm{Cr}$ among the pools. In general, binding of the metal was significantly weaker (Fig. 2). Labile fraction F0 and F1 comprised 34.45 and $11.50 \%$, respectively, of the total adsorbed load, whereas stable F5 and F4 comprised 25.47 and $10.66 \%$, respectively. Moreover, the fractions F2 and F3 contained, as in the case of $\mathrm{Cr}(\mathrm{III}), 11.65$ and $6.26 \%$ of the total adsorbed load, respectively (Table 2). The concentration of $\mathrm{Cr}(\mathrm{VI})$ ions in the water extract of the sample (F0) indicated the sole occurrence of $\mathrm{Cr}(\mathrm{VI})$. According to UV-Vis spectroscopy, the average level of $\mathrm{Cr}(\mathrm{VI})$ was $2,670 \mathrm{mg} \mathrm{kg}^{-1}$. A similar level of $\mathrm{Cr}(\mathrm{VI})$ was determined by atomic absorption spectrophotometry. The slight differences in the measured content of bound $\mathrm{Cr}$ likely reflect the different number of replicates we used for the assays.

Photosynthetic Activity

$F_{V} / F_{M}$

The physiological parameter as counted out from chlorophyll fluorescence induction measurements is widely interpreted as a potential efficiency of photosynthetic energy conversion in PSII (Strasser et al. 2000). This parameter was not significantly influenced by the presence of 0.5 and $1 \mathrm{mM} \mathrm{Cr}$ (III) during 5 days of plant incubation (Fig. 3a). The $\mathrm{Cr}$ (III) concentrations of $1.5 \mathrm{mM}$, and especially $2 \mathrm{mM}$, caused a significant decrease in the PSII activity/photosynthetic electron flow in PSII. The highest tested concentration of $\mathrm{Cr}(\mathrm{III})(4 \mathrm{mM})$ inhibited photosynthesis starting from the day 3 of incubation, but the level of energy conversion was greater than that prompted by 1.5 and $2 \mathrm{mM} \mathrm{Cr}$ concentrations. Statistical analysis showed that $F_{\mathrm{V}} / F_{\mathrm{M}}$ was influenced by $\mathrm{Cr}(\mathrm{VI})$ on the days

Table 2 Chemical fractionation $\left(\mathrm{mg} \mathrm{kg}^{-1} \mathrm{dw}\right)$ of natural organic matter of C. cophocarpa after incubation of plants in $4 \mathrm{mM} \mathrm{Cr}$ concentration

\begin{tabular}{|c|c|c|c|c|c|c|c|c|c|c|c|c|c|c|}
\hline \multirow{2}{*}{$\begin{array}{l}\text { Chemical } \\
\text { fractionation }\end{array}$} & \multicolumn{2}{|l|}{ F0 } & \multicolumn{2}{|l|}{$\mathrm{F} 1$} & \multicolumn{2}{|l|}{ F2 } & \multicolumn{2}{|l|}{ F3 } & \multicolumn{2}{|l|}{$\mathrm{F} 4$} & \multicolumn{2}{|l|}{ F5 } & \multicolumn{2}{|c|}{ 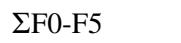 } \\
\hline & Mean & SD & Mean & SD & Mean & SD & Mean & SD & Mean & SD & Mean & SD & Mean & SD \\
\hline $\mathrm{Cr}(\mathrm{III})$ & 748 & 0.48 & 1975 & 0.46 & 4043 & 1.01 & 1614 & 1.67 & 11876 & 1.27 & 9100 & 2.50 & 29356 & 7.40 \\
\hline $\mathrm{Cr}(\mathrm{VI})$ & 2689 & 3.76 & 896 & 0.80 & 909 & 1.13 & 481 & 1.78 & 831 & 0.84 & 1990 & 3.66 & 7795 & 8.40 \\
\hline
\end{tabular}

$\mathrm{FO}$ pool of $\mathrm{Cr}$ ions occurring in the free-water space of the cell wall (the water-soluble fraction), $F 1$ and $F 2$ pools of $\mathrm{Cr}$ ions bound by the electrostatic, hydrogen, and Van der Waals' attraction (mobile fractions), $F 3$ and $F 4$ pools of $C r$ ions trapped by chelation/complexation process (mobilizable fractions), F5 pool of very strong stable binding of Cr ions. Three independent measurements were performed for each sample; SD (\%) 

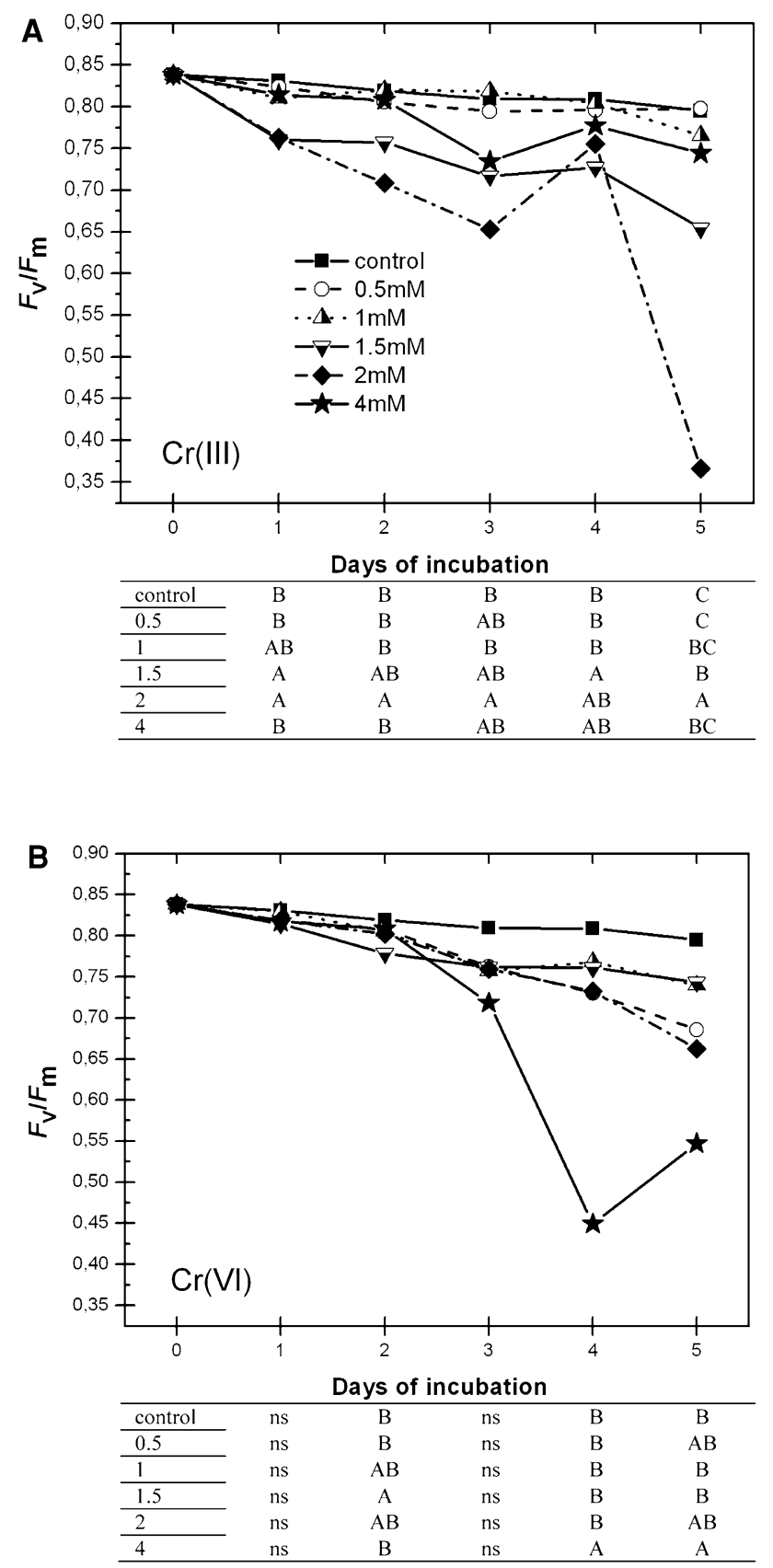

Fig. 3 Maximum quantum yield of PSII $\left(F_{\mathrm{V}} / F_{\mathrm{M}}\right)$ in leaves exposed to different $\mathrm{Cr}(\mathrm{III})$ and $\mathrm{Cr}(\mathrm{VI})$ concentrations during a 5-day incubation. Ten independent replicates were performed for each measurement. The columns of tables correspond to the days of incubation, and different letters denote statistically significant differences (ANOVA and Tukey's test; $P \leq 0.05$ ); $n s$ not significant

2, 4, and 5 of the incubation (Fig. 3b). On day 2, the level of PSII activity was significantly decreased only in the sample containing $1.5 \mathrm{mM} \mathrm{Cr}(\mathrm{VI})$. The $0.5 \mathrm{mM} \mathrm{Cr}(\mathrm{VI})$ concentration caused a much stronger final effect on photosynthetic electron transport than $\mathrm{Cr}(\mathrm{III})$ at the same concentration. Surprisingly, on day 5 of incubation, the lowest $\mathrm{Cr}(\mathrm{VI})$ concentration exhibited an effect similar to the $2 \mathrm{mM}$ concentration of $\mathrm{Cr}(\mathrm{VI})$. Results obtained for 1 , 1.5 , and $2 \mathrm{mM} \mathrm{Cr}(\mathrm{VI})$ were similar in the days following. The most negative influence of $\mathrm{Cr}(\mathrm{VI})$ on PSII activity was observed in the case of $4 \mathrm{mM} \mathrm{Cr}(\mathrm{VI})$.

\section{Discussion}

Pollution with $\mathrm{Cr}$ compounds is a very serious environmental problem worldwide, affecting both the developed (e.g., the USA, where it is regarded as a priority contaminant by the United States Environmental Protection Agency) and developing (e.g., India) countries. Phytoremediation of water performed by vascular plants (macrophytes) is a competitive strategy compared with other bioremediation methods using prokaryotic and eukaryotic organisms, such as bacteria, unicellular algae, and yeast. Benefits arising from the use of vascular plants are related mainly to the ease of collecting material and no risk of migration of organisms in the soil-water environment. High phytoremediation potential of water macrophytes, especially occurring in hot climate zones, has been well documented in the literature (Dhote and Dixit 2009); however, the data concerning $\mathrm{Cr}$ are relatively scarce compared with that of other metal elements.

The idea of the present work was to find out, under laboratory conditions, whether $C$. cophocarpa could be an effective biofilter of the dissolved and highly-concentrated $\mathrm{Cr}(\mathrm{III})$ and $\mathrm{Cr}(\mathrm{VI})$ ions. The plant material was not grown in polluted environment, but it was moved to the contaminated water in the laboratory conditions to elucidate its potential biofiltering efficiency. Therefore, a live plant material and the water from the natural plant stand (filtrated to limit growth of algae and bacteria) was used for the experiments instead of the synthetic media. The $\mathrm{pH}$ of the $\mathrm{Cr}(\mathrm{VI})$ solutions was not manipulated. The $\mathrm{pH}$ of $\mathrm{Cr}$ (III) media had to be decreased to prevent chemical $\mathrm{Cr}(\mathrm{III})$ precipitation. The study also determined the binding strength of $\mathrm{Cr}$ onto the plant material and that is crucial for further appropriate use of this species as in low-cost treatment technologies. In the work reported here, we focused on the environmental significance of $C$. cophocarpa by testing it under semi-natural conditions.

Callitriche cophocarpa has been recently identified as a promising phytoremediator of low-concentrated $\mathrm{Cr}(\mathrm{VI})$ in aquatic systems (Augustynowicz et al. 2010). In the current study, high concentrations of both $\mathrm{Cr}$ oxidation states ( $\mathrm{Cr}(\mathrm{III})$ and $\mathrm{Cr}(\mathrm{VI})$ ) were used. In relation to other heavy metal aquatic phytoremediators (Zayed and Terry 2003), the average level of $\mathrm{Cr}$ accumulation by the shoots of Callitriche was extremely high, reaching almost 3 and $0.73 \% \mathrm{dw}$, respectively, in the case of plant material incubated in $\mathrm{Cr}(\mathrm{III})$ and $\mathrm{Cr}(\mathrm{VI})$. Very significant values of 
Cr removal capacity and bioconcentration factors were also found. The above-mentioned parameters were comparable with those found in $\mathrm{Cr}$ aquatic hyperaccumulators as recently discovered Leersia hexandra. The greatest bioaccumulation coefficients of $\mathrm{Cr}$ in leaves of Leersia is 487 for $\mathrm{Cr}$ (III) and 72 for $\mathrm{Cr}(\mathrm{VI})$ (Zhang et al. 2007). Our results confirm the data reported earlier and indicate that aquatic macrophytes can accumulate more $\mathrm{Cr}(\mathrm{III})$ than $\mathrm{Cr}(\mathrm{VI})$ (Zayed and Terry 2003).

Uptake of $\mathrm{Cr}$ by plants is dependent on the oxidation state of the metal. In water systems under $E_{\mathrm{h}}$ ranging from 0 to $1,200 \mathrm{mV}$ and $\mathrm{pH}<5.0$ (conditions like the ones of our experiment), the main $\mathrm{Cr}$ (III) species include cations $\mathrm{Cr}^{3+}$ and $\mathrm{CrOH}^{2+}$. At $\mathrm{pH}$ values greater than 13.5 and $E_{\mathrm{h}}$ ranging from 50 to $-800 \mathrm{mV}$, soluble $\mathrm{Cr}(\mathrm{III})$ anions are formed $\left(\mathrm{CrO}^{2-}\right)$. In contrast, under the experimental conditions used in this study ( $\mathrm{pH}$ from 6.0 to $14.0, E_{\mathrm{h}}$ from -100 to $900 \mathrm{mV}), \mathrm{Cr}(\mathrm{VI})$ forms soluble chromate $\left(\mathrm{CrO}_{4}{ }^{2-}\right)$ anions (Brookins 1987). Consequently, distinct mechanisms are engaged in $\mathrm{Cr}$ binding to plants. $\mathrm{Cr}$ (III) accumulation is a passive process performed in two steps. The first step is based on the diffusion of $\mathrm{Cr}(\mathrm{III})$ ions across the cell wall and plasma membranes. This step is then followed by sorption of the cations onto the plant cell walls by way of different mechanisms that include (1) an electrostatic, hydrogen, and Van der Waals' interaction between $\mathrm{Cr}$ ions and surface wall, (2) the chelation/complexes reaction between $\mathrm{Cr}$ ions and different chemical groups, e.g., hydroxyl, carboxyl, amide, sulfhydryl from the plasmalemma/cell wall, and (3) the exchange ion reaction between $\mathrm{Cr}$ and cations located in the surface functional groups instead of $\mathrm{H}^{+}$(Kotaś and Stasicka 2000; Mohan and Pittman 2006). Compared with Cr(III) uptake, $\mathrm{Cr}(\mathrm{VI})$ anions are actively transported into the plant cells under control of sulphate transporters (Kaszycki et al. 2005; Appenroth et al. 2008). Passive sorption of $\mathrm{Cr}(\mathrm{VI})$ ions to the plant surface is far less pronounced than $\mathrm{Cr}(\mathrm{III})$ due to the differences in structure and toxicity of both ions. However, $\mathrm{Cr}(\mathrm{VI})$ could be reduced to $\mathrm{Cr}(\mathrm{III})$ by plants followed by sorption of the ions to the plant cell surfaces, which is an important phytoremediation strategy (Zayed and Terry 2003; Zazo et al. 2008; Espinoza-Quiñones et al. 2009). The ability of $C$. cophocarpa to reduce $\mathrm{Cr}$ (VI) to $\mathrm{Cr}$ (III) was shown using electron paramagnetic resonance spectroscopy (EPR; L-band) (Augustynowicz et al. 2009). In addition, recent experiments (Augustynowicz et al. 2012) conducted under the same conditions as those described herein showed that no plant-induced $\mathrm{Cr}(\mathrm{VI})$ reduction accompanying $\mathrm{Cr}$ accumulation was observed in $\mathrm{Cr}(\mathrm{VI})$ solutions. However, EPR spectroscopy showed that a biphasic signal of $\mathrm{Cr}(\mathrm{V})$ attending $\mathrm{Cr}(\mathrm{VI})$ to $\mathrm{Cr}(\mathrm{III})$ reduction was detected inside plant tissue every day during the study. Our results showed that phytoextraction, but not phytostabilization, is the main strategy of $\mathrm{Cr}(\mathrm{VI})$ detoxification by $C$. cophocarpa in aquatic systems. Based on the pattern of mean values found in the removal test (Fig. 1b), we postulate that different mechanisms of $\mathrm{Cr}$ uptake are involved in cases of $\mathrm{Cr}(\mathrm{III})$ and $\mathrm{Cr}(\mathrm{VI})$.

The SE method used in the study reported here was chosen as a standard technique that is useful in measurement of the strength of metal binding to organic matter. Because the interactions of $\mathrm{Cr}$ ions with proteins and other cell components are known, other conditions of sample preparation, e.g., air- or freeze-drying of samples instead of temperature-drying them, will be tested in the near future. SE exhibited a distinct valence-dependent metal-binding strength to the shoots of $C$. cophocarpa. We showed that the major pool of bound $\mathrm{Cr}(\mathrm{III})$ ions follows the strongest mechanism of metal binding to the organic matter, and the pool was located within the cell in the form of the chelate/ complexes with surface organic groups. The results of fractionation of the $\mathrm{Cr}$ ions adsorbed by the plant after sample incubation in $\mathrm{Cr}$ (III) solution are consistent with the results of the chemical extraction from materials rich in organic matter (Kyzioł-Komosińska et al. 2006) and from the use of heterogenic materials (Romaguera et al. 2008; Lesven et al. 2009). In the present study, we have shown that there is no risk for secondary contamination of the aquatic environment by $\mathrm{Cr}$ discharging after saturation of Callitriche sorption capacity by $\mathrm{Cr}(\mathrm{III})$ ions. In contrast, cautious treatment of plant material accompanying $\mathrm{Cr}(\mathrm{VI})$ sorption is suggested. Although approximately $25 \%$ of total $\mathrm{Cr}$ was also very strongly incorporated into plant tissue, a high amount of $\mathrm{Cr}$ was weakly bound to organic matter, $34 \%$ in water soluble fraction and the next $23 \%$ as easily mobile fractions. The analysis confirmed that only $\mathrm{Cr}(\mathrm{VI})$ ions, but not $\mathrm{Cr}(\mathrm{III})$ ions, are present in water extract of samples incubated in $\mathrm{Cr}(\mathrm{VI})$. Therefore, only the $\mathrm{Cr}(\mathrm{VI})$ fraction is susceptible to an easy release. To prevent contamination of soil and water with the desorbed $\mathrm{Cr}(\mathrm{VI})$ ions, the plant material, which was previously saturated with $\mathrm{Cr}(\mathrm{VI})$ should be stored in an isolated dry place until its disposal. The best way to dispose of the waste organic sorbent should include thermal treatment (incineration).

To evaluate the mechanism of physicochemical or metabolically derived $\mathrm{Cr}$ uptake by Callitriche, we studied the status of PSII activity, which is known to be very sensitive to the presence of heavy metals. Chlorophyll a fluorescence induction curve analysis was performed. This technique has been proven to be fast, nondestructive, and useful for studying the effects of different abiotic stresses on plants (Myśliwa-Kurdziel et al. 2004). According to the extremely high unphysiological concentration of $\mathrm{Cr}$ used in the present study, we had assumed physicochemical $\mathrm{Cr}$ binding by the plant under these conditions. However, taking into consideration the status of plants measured by way of efficiency of 
the photosynthetic energy conversion, a contribution of passive or active $\mathrm{Cr}$ transport and/or metabolic processes in $\mathrm{Cr}$ accumulation by the species in these highly concentrated metal solutions cannot be excluded. Changes of the $F_{\mathrm{V}} / F_{\mathrm{M}}$ parameter shows that action of both $\mathrm{Cr}$ (III) and $\mathrm{Cr}(\mathrm{VI})$ on Callitriche plants cause a decrease in the photosynthetic activity, but the metabolism of the cells remain still active. The effect of both $\mathrm{Cr}$ forms on Callitriche is not strictly concentration dependent. $\mathrm{Cr}$ (III) ions at 1.5 and $2 \mathrm{mM}$ concentrations showed far stronger effects than that of $4 \mathrm{mM}$. Furthermore, $0.5 \mathrm{mM} \mathrm{Cr}(\mathrm{VI})$ caused an $F_{\mathrm{V}} / F_{\mathrm{M}}$ decrease comparable with that of $2 \mathrm{mM}$ and much greater that that of 1 and $1.5 \mathrm{mM}$. This observation is not consistent with our earlier observation concerning the action of a lower $\mathrm{Cr}$ (VI) concentration (Augustynowicz et al. 2010) as well as the one reported by other investigators (Hörcsik et al. 2007; Oláh et al. 2010). In the previously mentioned works, direct dependence of $\mathrm{Cr}(\mathrm{VI})$ on $F_{\mathrm{V}} / F_{\mathrm{M}}$ was measured. There are possibly two explanations for this phenomenon. First, our earlier work was performed in synthetic media with lower $\mathrm{pH}$, which is known to favor higher redox activity of $\mathrm{Cr}(\mathrm{VI})$ (Kotaś and Stasicka 2000). Consequently, the negative influence of $\mathrm{Cr}(\mathrm{VI})$ on plant metabolism, following the decrease in efficiency of photosynthetic energy conversion in PSII, is more pronounced in media with lower $\mathrm{pH}$. Second, we can speculate that different resistance mechanisms may be active in plants at the applied $\mathrm{Cr}$ concentration. Another evidence of possible active metabolism contribution in $\mathrm{Cr}$ transport in Callitriche might be a result of $\mathrm{pH}$ change. $\mathrm{We}$ speculate that the $\mathrm{pH}$ increase in $\mathrm{Cr}(\mathrm{VI})$ solutions could be an effect of metabolically derived transport of $\mathrm{Cr}(\mathrm{VI})$ anions (e.g., $\mathrm{Cr}_{2} \mathrm{O}_{7}{ }^{2-}$ ) that coincide with the efflux of $\mathrm{OH}^{-}$ $\left(\mathrm{HCO}_{3}{ }^{-}\right)$. The increase in $\mathrm{pH}$ value of $\mathrm{Cr}(\mathrm{VI})$-enriched nutrient media was also observed by Espinoza-Quiñones et al. (2009) in the study of Eichhornia crassipes, Salvinia auriculata, and Pistia stratiotes. In contrast, the $\mathrm{pH}$ increase in the $\mathrm{Cr}(\mathrm{III})$ media $\left(\mathrm{Cr}_{2}\left(\mathrm{SO}_{4}\right)_{3}\right)$ might be triggered by preferential uptake of sulphate anions by plants instead of Cr(III) cations.

In the group of $\mathrm{Cr}$ adsorbents currently available, the most effective ones are activated carbons and ion-exchange resins. In the case of activated carbons, the calculated maximal Cr-adsorption capacities, depending on the type of material used, is in the range of approximately 0.15-30 \% (Mohan and Pittman 2006). However, high operational costs related to the costs of the material production and reactivation are the main disadvantages in their use. Therefore, naturally derived, low-cost sorbents, including zeolites, clay minerals, and oxides together with biosorbent, such as microorganism, algae, mosses, and higher plants are tested (Hawley et al. 2004; Mohan and Pittman 2006). According to the results of statistical analysis and by comparing the homogenous groups related to accumulation of $\mathrm{Cr}$, we assume that the maximal sorption capacity of $\mathrm{Cr}$ by $C$. cophocarpa has not yet been determined. Hence, our next study will focus on the exact calculation of the $\mathrm{Cr}$ accumulation capacity of Callitriche based on the adsorption models. For that reason, the Langmuir or Freundlich models could be used. It would allow evaluation of the maximal $\mathrm{Cr}$ sorption capacity of C. cophocarpa and compare it to other sorbents applied in $\mathrm{Cr}$ removal. However, it must be pointed out that calculated adsorption properties are usually not environmentally relevant due to the specific conditions used during the incubation procedure, such as very low $\mathrm{pH}$ or high temperature. Still, the extraordinary accumulation capacity of Cr ions by $C$. cophocarpa, found in the conditions reported in this study, is comparable with the ones described for commercially used sorbents.

In conclusion, $C$. cophocarpa was identified as an effective biofilter of dissolved $\mathrm{Cr}$ ions in a contaminated aquatic environment. Our results indicate that this plant can be used as an efficient, low-cost $\mathrm{Cr}$ biosorbent for further use in wastewater purification technologies.

Acknowledgments We are indebted to Tomasz Kowalski (Czaple Wielkie, Poland) for invaluable help identifying Callitriche natural stands. We are also grateful to Wiesław Knap from the AGH University of Science and Technology, Department of Hydrogeology and Geological Engineering, Kraków, Poland, for the determination of water composition; Anna Kołton (University of Agriculture, Kraków, Poland) for assistance with measuring of chlorophyll fluorescence and preparing statistical analysis; and Dorota Wójcik (University of Agriculture, Kraków, Poland) for technical assistance during sample mineralization. Critical reading of the manuscript and English improvement by Arek Kulczyk (Harvard University, Boston, USA) and Maria Leja (Univeristy of Agriculture, Kraków, Poland) is highly appreciated. The work was supported by the Grant No. DEC-2011/03/ B/NZ9/00952 from the National Science Centre, Poland.

Open Access This article is distributed under the terms of the Creative Commons Attribution License which permits any use, distribution, and reproduction in any medium, provided the original author(s) and the source are credited.

\section{References}

Alomary AA, Belhadj S (2007) Determination of heavy metals (Cd, $\mathrm{Cr}, \mathrm{Cu}, \mathrm{Fe}, \mathrm{Ni}, \mathrm{Pb}, \mathrm{Zn}$ ) by ICP-OES and their speciation in Algerian Mediterranean Sea sediments after a five-stage sequential extraction procedure. Environ Monit Assess 135:265-280

Appenroth K-J, Luther A, Jetschke G, Gabrys H (2008) Modification of chromate toxicity by sulphate in duckweeds (Lemnaceae). Aquat Toxicol 89:167-171

Augustynowicz J, Kostecka-Gugała A, Kołoczek H (2009) Analysis of kinetics of $\mathrm{Cr}(\mathrm{VI})$ reduction by aquatic phytoremediators. Environ Prot Nat Resour 41:210-219 (in Polish)

Augustynowicz J, Grosicki M, Hanus-Fajerska E, Lekka M, Waloszek A, Kołoczek H (2010) Chromium(VI) bioremediation by aquatic macrophyte Callitriche cophocarpa Sendtn. Chemosphere 79:1077-1083 
Augustynowicz J, Kołton A, Baran A, Kostecka-Gugała A, Lasek W (2012) Strategy of Cr detoxification by Callitriche cophocarpa. Central Eur J Chem. doi:10.2478/s11532-012-0161-8

Ayari F, Chairi R, Kossai R (2008) Sequential extraction of heavy metals during composting of urban waste. Chin $\mathrm{J}$ Geochem 27:121-125

Brookins D (1987) Eh-pH diagrams for geochemistry. Springer, New York

Dhote S, Dixit S (2009) Water quality improvement through macrophytes - a review. Environ Monit Assess 152(1-4):149-153

Espinoza-Quiñones FR, Martin N, Stutz G, Tirao G, Palácio SM, Rizzutto MA et al (2009) Root uptake and reduction of hexavalent chromium by aquatic macrophytes as assessed by high-resolution X-ray emission. Water Res 43:4159-4166

Hawley EL, Deeb RA, Kavanaugh MC, Jacobs JA (2004) Treatment technologies for chromium(VI). In: Guertin J, Jacobs JA, Avakian CP (eds) Chromium(VI) handbook. CRC Press, Boca Raton, pp 273-308

Hörcsik ZT, Kovács L, Láposi R, Mészáros I, Lakatos G, Garab G (2007) Effect of chromium on photosystem 2 in the unicellular green alga, Chlorella pyrenoidosa. Photosynthetica 45:65-69

Jain CK, Gupta H, Chakrapani GJ (2008) Enrichment and fractionation of heavy metals in bed sediments of River Narmada, India. Environ Monit Assess 141:35-47

Jaradat QM, Massadeh AM, Zaitoun MZ, Maitah BM (2006) Fractionation and sequential extraction of heavy metals in the soil of scrapyard of discarded vehicles. Environ Monit Assess 112:197-210

Kabata-Pendias A, Mukherjee AB (2007) Trace elements from soil to human. Springer, Berlin, pp 173-183

Kaszycki P, Gabryś H, Appenroth K-J, Jaglarz A, Sędziwy S, Walczak T et al (2005) Exogenously applied sulphate as a tool to investigate transport and reduction of chromate in the duckweed Spirodela polyrhiza. Plant Cell Environ 28:260-268

Kersten M, Förstner U (1990) Speciation of trace elements in sediments. In: Batley GE (ed) Trace element speciation: analytical methods and problems. CRC Press, Boca Raton, pp 245-317

Kotaś J, Stasicka Z (2000) Chromium occurrence in the environment and methods of its speciation. Environ Pollut 107:263-283

Kyzioł-Komosińska J, Kukułka L (2008) Application of minerals co-occurring in brown coal deposits to removal of heavy metals from water and wastewater. Works and Studies 75. Polish Academy of Sciences, Zabrze (in Polish)

Kyzioł-Komosińska J, Twardowska I, Schmitt-Kopplin Ph (2006) The role of humic substances in chromium sorption onto natural organic matter (peat). Chemosphere 63:1974-1982

Lesven L, Lourino-Cabana B, Billon G, Proix N, Recourt P, Ouddane $\mathrm{B}$ et al (2009) Water-quality diagnosis and metal distribution in a strongly polluted zone of Deûle River (northern France). Water Air Soil Pollut 198:31-44

Maxwell K, Johnson GN (2000) Chlorophyll fluorescence-a practical guide. J Exp Bot 51:659-668

Mohan D, Pittman ChU Jr (2006) Activated carbon and low cost adsorbents for remediation of tri- and hexavalent chromium form water. J Hazard Mater 137:762-811
Mouvet Ch, Claveri B (1999) Localization of copper accumulated in Rhynchostegium riparioides using sequential chemical extraction. Aquat Bot 63:1-10

Myśliwa-Kurdziel B, Prasad MNV, Strzłka K (2004) Photosynthesis in heavy metal stressed plants. In: Prasad MNV (ed) Heavy metal stress in plants: from biomolecules to ecosystems, 2nd edn. Springer, Berlin, pp 146-181

Oláh V, Lakatos G, Bertók C, Kanalas P, Szöllösi E, Kis J et al (2010) Short-term chromium(VI) stress induces different photosynthetic responses in two duckweed species Lemna gibba L. and Lemna minor L. Photosynthetica 48:513-520

PN-EN ISO 17294-1:2007: water quality—application of inductively coupled plasma mass spectrometry (ICP-MS) - Part 1: general guidelines. Polish Committee for Standardization, Warsaw, Poland

PN-EN ISO 9963-1:2001: water quality-determination of alkalinity-Part 1: determination of total and composite alkalinity. Polish Committee for Standardization, Warsaw, Poland

PN-ISO 9297:1994: water quality-determination of chloride—silver nitrate titration with chromate indicator (Mohr's method). Polish Committee for Standardization, Warsaw, Poland

Prasad MNV (2004) Phytoremediation of metals and radionuclides in the environment: the case for natural hyperaccumulators, metal transporters, soil-amending chelators and transgenic plants. In: Prasad MNV (ed) Heavy metal stress in plants: from biomolecules to ecosystems, 2nd edn. Springer, Berlin, pp 345-391

Romaguera F, Boluda R, Fornes F, Abad M (2008) Comparison of three sequential extraction procedures for trace element partitioning in three contaminated Mediterranean soils. Environ Geochem Health 30:171-175

Soco E, Kalembkiewicz J (2009) Investigations on Cr mobility from coal fly ash. Fuel 88:1513-1519

Strasser RJ, Srivastava A, Tsimilli-Michael M (2000) The fluorescence transient as a tool to characterize and screen photosynthetic samples. In: Yunus M, Pathre U, Mohanty P (eds) Probing photosynthesis: mechanism, regulation and adaptation. Taylor and Francis, London, pp 443-480

Strasser RJ, Tsimilli-Michael M, Srivastava A (2004) Analysis of the chlorophyll a fluorescence transient. In: Papageorgiou GC, Govindjee (eds) Chlorophyll fluorescence: a signature of photosynthesis. Advances in photosynthesis and respiration series (Govindjee series), vol 19. Kluwer Academic Press, Rotterdam, pp 321-362

Tessier A, Campbell PGC, Bisson M (1979) Sequential extraction procedure for the speciation of particular trace metals. Anal Chem 51:844-850

Zayed AM, Terry N (2003) Chromium in the environment: factors affecting biological remediation. Plant Soil 249:139-156

Zazo JA, Paull JS, Jaffe PR (2008) Influence of plants on the reduction of hexavalent chromium in wetland sediments. Environ Pollut 156:29-35

Zhang X-H, Liu J, Huang H-T, Chen J, Zhu Y-N, Wang D-Q (2007) Chromium accumulation by the hyperaccumulator plant Leersia hexandra Swartz. Chemosphere 67:1138-1143 